\title{
PENOKOHAN DALAM KARYA FIKSI
}

\author{
Hikma H. Amidong \\ Fakultas Sastra, Universitas Muslim Indonesia \\ Jalan Urip Sumoharjo KM 5, Makassar \\ Hikmaa54@gmail.com
}

\begin{abstract}
Abstrak: Fiksi merupakan salah bentuk narasi yang mempunyai sifat berbentuk cerita. Penokohan adalah cara pengarang menampilkan tokoh dalam ceritanya dan bagaimana tokoh-tokoh tersebut. Dalam penokohan, watak atau karakter seorang tokoh dapat dilihat dari tiga segi yaitu, dialog tokoh, penjelasan tokoh, dan Penggambaran fisik. Ada dua jenis penokohan, yaitu: Secara langsung atau deskriptif/analitik, dan Teknik dramatik. Secara langsung atau deskriftif/analitik adalah dimana pengarang langsung melukiskan atau menyebutkan secara terperinci bagaimana watak sang tokoh, bagaimana ciri-ciri fisiknya, apa pekerjaannya, dan sebagainya. Sedangkan, Secara tidak langsung/dramatik adalah dimana pengarang melukiskan sifat dan ciri fisik sang tokoh melalui reaksi tokoh lain terhadap tokoh sentral, melalui gambaran lingkungan sekitar tokoh sentral, serta dapat diungkapkan melalui percakapan antar tokoh dalam cerita tersebut. Berhadapan dengan tokoh-tokoh fiksi pembaca sering memberikan reaksi emotif tertentu seperti merasa akrab, simpati, empati, benci, antipati, atau berbagai reaksi afektif lainnya. Tidak jarang pembaca mengidentifikasikan dirinya dengan tokohnya yang diberinya seperti simpati dan empati
\end{abstract}

Kata kunci: Penokohan, karya fiksi

\section{PENDAHULUAN}

Sastra adalah sebuah karya yang indah, baik itu tulisan serta juga lisan. Dengan berdasarkan dari asal usul, definisi sastra diistilahkan ialah sebagai "kesuasastraan" susatra yang berasal dari bahasa sansekerta, yakni sastra. "su" yang berartikan bagus atau juga indah, sedangkan dari "sastra" yang berartikan "buku, tulisan atau juga huruf'. Dengan secara etimologi, dari arti kedua kata tersebut bisa disimpulkan bahwa arti dari "susastra atau sastra" adalah suatu tulisan yang indah.

Sastra dapat digolongkan menjadi beberapa jenis. Pembagian jenis-jenis sastra adalah, prosa, puisi, dan drama. Prosa dalah karya sastra yang berupa cerita yang berupa paragraf yang berisi rangkaian cerita. Yang termasuk dalam prosa adalah cerpen dan novel. Cerpen adalah karya sastra yang berupa cerita yang hanya memiliki satu konflik, dan panjanggnya tidak lebih dari seribu kata. Menurut Umar Mansyur, (2016: 332) Cerita pendek atau yang biasa disingkat cerpen adalah karya sastra yang berbentuk prosa. Cerpen dapat menampilkan persoalan manusia dengan liku-liku kehidupannya. Oleh karena bentuknya pendek cerpen menuntut penceritaan yang serba ringkas tidak sampai pada deti-detil khusus yang kurang penting yang lebih bersifat memperpanjang cerita. Novel adalah karya sastra yang berisi cerita yang panjang dan kompleks.

Puisi adalah karya sastra yang berisi bait dan baris yang singkat dan padat. 
Mengutamakan penggunaan kata (diksi) yang indah. Karya sastra puisi adalah karya sastra yang sulit dipahami karena baris yang singkat dan padat.

Drama adalah karya sastra yang berupa percakapan antar tokoh yang terdapat di dalamnya. Meskipun ada yang menyebut bahwa drama adalah bagian dari prosa, tetapi tidak sedikit pula para ahli yang berpendapat bahwa drama adalah jenis sastra tersendiri.

Telah dijelaskan di atas bahwa jenis prosa ada dua yaitu cerpen dan novel. Dalam cerpen atau novel mengandung unsur intrinsik yang terdapat di dalam cepen maupun novel. Salah satu dari unsur intrinsik adalah penokohan. Penokohan adalah cara pengarang menampilkan tokohtokoh dalam cerita sehingga dapat diketahui karakter atau sifat para tokoh itu. Untuk lebih memahami tentang penokohan, penulis menyajikan karya ilmiah tentang "Penokohan dalam karya fiksi".

\section{PEMBAHASAN}

\section{A. Unsur Penokohan Dalam Fiksi}

Sama halnya dengan unsur plot dan pemlotan, tokoh dan penokohan merupakan unsur yang penting dalam cerita fiksi. Plot boleh saja dipandang orang sebagai tulang punggung cerita, namun kita pun dapat mempersoalkan siapa yang diceritakan itu? Siapa yang melakukan sesuatu dan dikenai sesuatu, " sesuatu" yang dalam plot disebut sebagai peristiwa, siapa pembuat komplik, dan lain-lain adalah urusan tokoh dan penokohan. Pembicaraan mengenai tokoh dengan segala perwatakan dengan berbagai citra jati dirinya, dalam banyak hal, lebih menarik perhatian orang daripada berurusan dengan pemlotannya. Namun, hal itu tak berarti unsur plot dapat diabaikan begitu saja karena kejelasan mengenai tokoh dan penokohan dalam banyak hal tergantung pada pemlotannya.

\section{Pengertian dan Hakikat Penokohan}

Dalam pembicaraan sebuah cerita fiksi, sering dipergunakan istilah-istilah seperti tokoh dan penokohan, watak dan perwatakan, atau karakter dan karakterisasi secara bergantian dengan menunjuk pengertian yang hampir sama. Istilah-istilah tersebut sebenarnya, tidak menyaran pada pengertian yang persis sama, atau paling tidak dalam tulisan ini akan dipergunakan dalam pengertian yang berbeda walau memang ada diantaranya yang sinonim. Penokohan merupakan salah satu unsur penting untuk membangun sebuah struktur yang kehadirannya sangat diperlukan dalam cerita. Menurut Jones (dalam Nurgiantoro, 1995: 165) penokohan adalah penggambaran yang jelas tentang seseorang yang ditampilkan dalam sebuah cerita, sedangkan Sudjiman (1988: 23) menyebutkan bahwa penokohan merupakan penyajian watak tokoh penciptaan citra tokoh.

Menurut Aminuddin (dalam Prima Fajri Putra, 2014: 10), tokoh adalah pelaku yang mengemban peristiwa dalam cerita. Sedangkan penokohan adalah cara pengarang menampilkan tokoh dalam ceritanya dan bagaimana tokoh-tokoh tersebut. Hal ini berarti ada dua hal yang penting, yang pertama berhubungan erat, penampilan dan penggambaran sang tokoh harus mendukung watak tokoh. Secara wajar, apabila penggambaran tokoh kurang selaras dengan watak yang dimilikinya atau bahkan sama sekali tidak mendukung watak 
tokoh yang digambarkan jelas akan mengurangi bobot ceritanya.

\section{Penokohan dan Unsur Fiksi Lain}

Fiksi merupakan sebuah keseluruhan yang utuh dan memiliki ciri artistik. Keutuhan dan keartistikan fiksi terletak pada keterjalinan yang erat antar berbagai unsur pembangunnya. Penokohan itu sendiri merupakan bagian, unsur, yang bersama unsur-unsur yang lain membentuk sebuah totalitas. Namun perlu dicatat, penokohan merupakan unsur yang penting dalam fiksi. Ia merupakan salah satu fakta cerita di samping. Keutuhan dan keartistikan fiksi terletak pada keterjalinan yang erat antarberbagai unsur pembangunannya. Penokohan itu merupakan bagian, unsur, yang bersama dengan unsur-unsur yang membentuk sebuah totalitas, Namun perlu dicatat, penokohan merupakan unsur yang penting dalam cerita fiksi. Ia merupakan salah satu fakta cerita disamping kedua fakta cerita yang lain. Dengan demikian penokohan mempunyai peranan yang besar dalam menentukan keutuhan dan keartistikan sebuah teks fiksi.

Penokohan sebagai salah satu unsur pembangun fiksi dapat dikaji dan dianalisis keterjalinannya dengan unsur-unsur pembangun lainnya. Jika fiksi yang bersangkutan merupakan sebuah karya yang berhasil, penokohan pasti berjalan secara harmonis dan saling melengkapi dengan berbagai unsur yang lain misalnya dengan unsur plot dan tema, atau unsur latar, sudut pandang, gaya amanat, dan lain-lain.

Penokohan dan Pemlotan. Dalam kehidupan sehari-hari manusia yang sebenranya tidak ada plot. Plot merupakan sesuatu yang bersifat artifisial. Ia pada hakikatnya hanya merupakan suatu bentuk pengalaman, yang sendiri sebenarnya tidak memiliki bentuk. Pemunculan peristiwa itu lebih merupakan suatu bentuk pengalaman yang sebenarnya tidak memiliki bentuk.

Penokohan dan pemlotan merupakan dua fakta cerita yang saling memengaruhi dan menggantungkan satu dengan yang lain. Plot adalah apa yang dilakukan tokoh dan apa yang menimpanya. Ada kejadian demi kejadian ketegangan konflik dan sampai ke klimaks yang kesemuanya merupakan halhal yang esensial dalam alur.

Penokohan dan tema. Sebenarnya dikemukakan sebelumnya, tema merupakan dasar cerita, gagasan sentral, atau makna cerita. Dengan demikian, dalam sebuah cerita fiksi, tema berfungsi mengikat menyatukan keseluruhan unsur fiksi tersebut. Sebagai unsur cerita itulah terutama yang sebgai pelaku penyampai tema secara terselubung ataupun terangterangan. Adanya perbedaan tema kan menyebabkan perbedaan pemerlakuan tokoh cerita yang "ditugasi" menyampaikannya. Pengarang pada umumnya akan memilih tokoh-tokoh tertentu yang dipertimbangkan paling sesuai untuk mendukung temanya.

Dalam kebanyakan cerita fiksi, tema umumnya tidak dinyatakan secara eksplisit. Hal itu berarti pembacalah yang "bertugas" menafsirkannya. Usaha penafsiran tema antara lain dapat dilakukan melalui kejadian dan atau konflik yang menonjol. Artinya, melalui konflik utama cerita, dan itu berarti konflik yang dialami, ditimbulkan, dan ditimpakan kepada tokoh utama. Artinya, usaha penafsiran tema sudah dilacak dari apa yang dilakukan, dipikirkan, dan dirasakan. 


\section{Relevansi Tokoh}

Berhadapan dengan tokoh-tokoh fiksi pembaca sering memberikan reaksi emotif tertentu seperti merasa akrab, simpati, empati, benci, antipati, atau berbagai reaksi afektif lainnya. Tidak jarang pembaca mengidentifikasikan dirinya dengan tokohnya yang diberinya seperti simpati dan empati. Segala apa yang dirasa oleh pembaca yang menyenangkan atau sebaliknya seolah-olah pembaca ikut merasakannya. Bahkan banyak tokoh yang menjadi pujaan pembaca dan masyarakat sehingga kehadirannya dalam cerita dinantikan sebagai kehadiran di dunia nyata. Pembaca telah merasa akrab betul dengan tokoh itu, atau bahkan seolah-olah menjadi bagian hidupnya walau secara fisik tidak dapat menginderainya. Tokoh cerita yang diperlukan demikian oleh pembaca, apakah berarti relevan?

Ada beberapa bentuk relevansi tokoh cerita. Seorang tokoh cerita yang ciptaan pengarang itu, jika disukai banyak orang dalam kehidupan nyata, apalagi sampai digandrungi, berarti merupakan tikoh fiksi yang mempunyai relevansi, Kemoy (dalam Nurgiantoro, 2015:257). Salah satu bentuk relevansi tokoh sering dihubungkan dengna keadaan keseperti pembaca, kitra, atau orang lain yang kita ketahui. Kita sering mengharapkan tokoh yang demikian.

Namun, sebenarnya hal itu tidak saja berarti membatasi kreativitas imajinasi pengarang, juga melupakan fungsi tokoh sebagai elemen fiksi. Pengarang mempunyai kebebasan menciptakan tokoh yang bagaimanapun, dengan hanya merasa terikat bahwa tokohnya relevan dengan pengalaman kehidupannya sendiri dan mungkin pembaca. Oleh karena itu, dalam kaitannya dengan relevansi ini, pertanyaaan yang diajukan tidak berbunyi "Apakah tokoh cerita itu seperti kita?", melainkan "Apakah relevansi tokoh bagi kita"?

Relevansi tokoh dan penokohan harus dilihat dalam kaitannya dengan berbagai unsur yang lain dan peranannya dalam cerita secara keseluruhan. tokoh memang unsur yang terpenting dalam cerita fiksi, namun, bagaimanapun juga, ia tetap terikat oleh unsu-unsur yang lain. Bagaimanapun jalinan dan bentuk keterikatan unsur tokoh dengan unsur-unsur yang lain dalam sebuah cerita fiksi, perlu ditinjau satu per satu. Jika tokoh memang berjalinan erat, saling melengkapi dan menentukan dengan unsur-unsur yang lain dalam membentuk keutuhan artistik, tokoh mempunyai bentuk relevan dengan cerita secara keseluruhan. Penokohan telah dikembangkan sesuai tuntutan cerita.

\section{Pembedaan Penokohan}

Dalam penokohan, watak atau karakter seorang tokoh dapat dilihat dari tiga segi, yaitu melalui: (1) Dialog tokoh, (2) penjelasan tokoh, dan (3) penggambaran fisik.

Selanjutnya, ada dua jenis penokohan, antara lain:

a) Secara langsung atau deskriftif/analitik

Dimana pengarang langsung melukiskan atau menyebutkan secara terperinci bagaimana watak sang tokoh, bagaimana ciri-ciri fisiknya, apa pekerjaannya, dan sebagainya. Jadi, tokoh cerita dihadirkan oleh pengarang ke hadapan pembaca secara langsung dan disertai dengan deskripsi kediriannya secara lengkap, 
yang dapat berupa sikap, sifat, watak, perilaku, atau ciri fisiknya.

Deskripsi kedirian tokoh yang dilakukan secara langsung oleh pengarang akan berwujud penuturan yang bersifat deskriptif pula. Pengarang menjelaskan kedirian tokoh dengan cepat dan singkat. Dengan demikian, pembaca kurang didorong untuk berperan dalam memberikan tanggapannya terhadap tokoh. Selain itu, penuturan dalam teknik ini bersifat mekanis dan kurang alami. Maksudnya, dalam realita yang ada, tidak orang yang mendeskripsikan kedirian seseorang secara lengkap. Misalkan, menerangkan kepada orang lain. Namun perlu diingat bahwa tak selamanya teknik analitis tidak cocok digunakan untuk menjelaskan kedirian seseorang. Teknik ekspositori biasa digunakan dengan efektif apabila penggunaannyan tepat sesuai porsinya.

b) Secara tidak langsung/dramatik, dimana pengarang melukiskan sifat dan ciri fisik sang tokoh melalui reaksi tokoh lain terhadap tokoh sentral, melalui gambaran lingkungan sekitar tokoh sentral, serta dapat diungkapkan melalui percakapan antar tokoh dalam cerita tersebut. Teknik dramatik dapat dilihat dari kutipan berikut:

"Setiap minggu Gita dan kakaknya Gagah melakukan kegiatan berbagi ke Mesjid. Selain itu, mereka selalu datang mendengarkan ceramah atau mengunjungi tempat Tabligh Akbar yang digelar oleh masyarakat. Gita terkadang memaksa agar orang tuanya datang pada acara amal seperti itu. Gita mulai paham mengenai kebutuhan rohani yang harus dilakukan. Gita terlibat memiliki diferensiasi yang baik karena dalam dirinya mulai berkembang pemikiran kritis mengenai agama." Sugiarto (dalam Arsya Prameswari 2017: 11)

Contohnya, ketika kita mengenal seseorang yang baru, kita tidak akan langsung menanyakan sifat orang tersebut, tetapi kita akan mencoba mengamati, katakatanya, sikapnya, serta pandanganpandangannya dalam kehidupan sehari-hari. Berangkat dari kutipan di atas, penggambaran tokoh Gita tidak diungkapkan secara gambling, melainkan melalui tingkah laku tokoh dan pemikirnya.

\section{PENUTUP}

Sastra adalah sebuah karya yang indah, baik itu tulisan serta juga lisan. Fiksi merupakan salah bentuk narasi yang mempunyai sifat berbentuk cerita. Prosa dalah karya sastra yang berupa cerita yang berupa paragraf yang berisi rangkaian cerita. Yang termasuk dalam prosa adalah cerpen dan novel. Cerpen adalah karya sastra yang berupa cerita yang hanya memiliki satu konflik, dan panjangnya tidak lebih dari seribu kata. Novel adalah karya sastra yang berisi cerita yang panjang dan komleks.

Penokohan adalah cara pengarang menampilkan tokoh dalam ceritanya dan bagaimana tokoh-tokoh tersebut. 


\section{DAFTAR PUSTAKA}

Burhan, Nurgiyantoro. 2015. Teori Pengkajian Fiksi. Yogyakarta: Gajah Mada University Press

Kerani. 2017. Sastra Adalah, Asal Usul, dan Pengertian Sastra. (kamusastra.blogspot.com/2017/04/sastra-adalah-asal-usul-dan-penertian.html?m=1, Diakses pada tanggal, 25 Oktober 2018)

Mansyur, Umar. 2018. Kiat dan Teknik Penulisan Skripsi bagi Mahasiswa. INA-Rxiv. https://doi.org/10.31227/osf.io/juds7

Mansyur, Umar. 2016. Pemanfaatan Nilai kejujuran dalam Cerpen sebagai Bahan Ajar Berbasis Pendidikan Karakter. In Mengais Karakter dalam Sastra: HISKI Makassar (pp. 330-339). https://doi.org/10.17605/OSF.IO/Z4T3Y

Muliadi. 2017. Buku Ajar Telaah Prosa (Sebuat Terapan). Makassar: De la macca

Nazira, Jimar. 2013. Tokoh dan Penokohan. (onjimarnazira.blogspot.com/2013/11/tokoh-danpenokohan.html?m=1, Diakses pada tanggal 11 Oktober 2018)

Pendidikanku. 2015. Pengertian Sastra, Ciri-Ciri Sastra, dan Fungsi Sastra. https://googleweblight.com/?u=https://pendidikanku.org/2015/04/penegrtian-sastra-ciriciri-sastra-dan.html?m\%3D1

Prameswari, Arsa. 2017. Makalah Kajian Prosa Fiksi Penokohan dan Krakterisasi dalam Prosa Fiksi.www.academia.edu/35640183/Makalah_Kajian_Prosa_Fiksi_Penokohan_Dan_Kar akteristik_Kelompok_4, Diakses pada tanggal, 25 Oktober 2018.

Putra, Fajri Prima. 2014. Penokohan Dan Perwatakan Novel Bumi Cinta Karya Habiburrahman El Shirazy. (repository.unib.ac.id, Diakses pada tanggal, 25 Oktober 2018)

Warnati. 2014. Tokoh dan Penokohan (Telaah Prosa). (nati094.blogspot.com, Diakses pada tanggal, 25 Oktober 2018) 